\title{
Evaluation of the morphological quality index in the Cordevole river (BI, Italy)
}

\author{
Emanuel Rigon, Johnny Moretto, Riccardo Rainato, Mario Aristide Lenzi, Andrea Zorzi \\ Department of Land, Environment, Agriculture and Forestry, University of Padua, Italy
}

\begin{abstract}
The European Union (EU) Water Framework Directive (WFD, 2000/60/EC), which came into force in Italy under Decree Law no. 152 of $3^{\text {rd }}$ April 2006, has as its objectives the protection and improvement of aquatic ecosystem status, promoting the sustainable use of water resources and mitigating the effects of floods and droughts. According to this Directive, the ecological classification of a watercourse should be considered in addition to physical-chemical and biological aspects of its hydromorphological condition, in order to define the deviation of the present condition from a pre-defined reference state. The Italian National Institute for Environmental Protection and Research has promoted a methodology called IDRAIM for the hydromorphological analysis of streams. This is an integrated approach aimed at implementing both WFD and EU Flood Directives (2007/60/EC). In this paper, we describe the application of the morphological quality index (MQI) protocol, which is part of the IDRAIM, used for evaluating the morphological quality of the Cordevole River, Province of Belluno, northeastern Italy. General settings and segmentation of the water network through the use of semi-automatic GIS techniques were presented. The MQI
\end{abstract}

Correspondence: Emanuel Rigon, Department of Land, Environment, Agriculture and Forestry, University of Padua, Italy.

E-mail: emanuel.rigon@unipd.it

Key words: hydromorphology, river network segmentation, morphological recovery, Water Framework Directive, Cordevole river, Italy.

Acknowledgements: this research was funded by the University of Padua Strategic Research Project PRST08001, GEORISKS, Geological, morphological and hydrological processes: monitoring, modelling and impact in NorthEastern Ital, Research Unit STPD08RWBY-004, the Project SedAlp: sediment management in Alpine basins, integrating sediment continuum, risk mitigation and hydropower, 83-4-3-AT, in the framework of the European Territorial Cooperation Programme Alpine Space 2007-2013, and the PRIN2010-11 Project National network for monitoring, modelling and sustainable management of erosion processes in agricultural land and hilly-mountainous area prot. 201D4ALME4. Thanks to the Regional Hydrological Service (ARPAV) for the Artificial Intervention Database.

Received for publication: 2 July 2013.

Accepted for publication: 10 November 2013.

(C) Copyright E. Rigon et al., 2013

Licensee PAGEPress, Italy

Journal of Agricultural Engineering 2013; XLIV:e15

doi:10.4081/jae.2013.e15

This article is distributed under the terms of the Creative Commons Attribution Noncommercial License (by-nc 3.0) which permits any noncommercial use, distribution, and reproduction in any medium, provided the original author(s) and source are credited. data derived from the application of 28 indicators in 42 reaches were then analysed. Most (48\%) of the analysed reaches have a good quality status; $38 \%$ have a moderate quality status and poor morphological conditions (14\%) are due to the presence of artificial elements and to the limited connectivity between hill-slopes and the river corridor.

\section{Introduction}

Many European rivers have suffered the negative consequence of different degrees and types of pressure from human activities that have modified their morphology and altered their hydrological processes (Liébault and Piégay, 2001; Gurnell et al., 2009). In recent years, the need has been recognised for a tool able to assess the ecological, morphological, hydrological conditions and the degree of alteration from the reference conditions of rivers. The main purpose of this tool is to define strategies of morphological recovery and plan river restoration management. The European Union (EU) Water Framework Directive (WFD; European Commission, 2000) and the EU Flood Directive (European Commission, 2007), define a series of innovative criteria and actions necessary for the ecological classification and management of European rivers. The WFD introduces the term hydromorphology that requires an interface among different topics and analyses the physical processes for river management actions and strategies (Vaughan et al., 2009). In this context, the modifications in flow and sediment regimes, morphology and lateral channel mobility must all be considered. It is still not clear which of the components are more strictly related to the ecological state, but it is now well known in the literature that the geomorphological processes promote the functionality of aquatic and riparian ecosystems (Palmer et al., 2005). The equilibrium of a river is the result of sedimentological and hydrological regimes, and can be modified by human action both directly by the alteration of these components or indirectly on the control variables (e.g. climate, forest area, etc.). The evaluation of the morphological and hydrological alteration allows the anthropic changes to the water channel to be assessed, and defines the evolutionary trends. River restoration strategies can then be defined. The evaluation of the morphological quality is particularly significant for rivers in Italy that, as in many other European countries, are characterised by a very high level of human pressure (Surian et al., 2009; Rigon et al., 2012b; Moretto et al., 2012).

The WFD that came into force in Italy under the Decree Law no. 152 of $3^{\text {rd }}$ April 2006 regulates the achievement by 2015 of a good ecological status for all natural water bodies, and the Italian Institute for Environmental Protection and Research (ISPRA) has recently promoted a new methodology, called IDRAIM, for the hydromorphological evaluation, analysis and monitoring of Italian streams. All local governments in Italy are working to implement the procedure, but the WFD objectives may not be achieved, especially for heavily modified water bodies (HMWB). The regulations provide for the deadline to be extended to achieve good ecological status. Currently in Italy the morphologi- 
cal evaluation procedure has been applied to around half of the regions, and the Region of Veneto is expected to apply it to its entire river network. In addition to the 102 river reaches analysed in the index test phase (Rinaldi et al., 2013), there are still very few publications available on the morphological evaluation carried out with this new methodology (Cencetti et al., 2010; Vangelista, 2011). ISPRA has now developed an initial screening procedure for the identification of HMWB. Only water bodies at risk of not achieving a good ecological status will be analysed by IDRAIM.

In this paper, we describe the application of the morphological quality index (MQI) protocol, which is part of IDRAIM (Rinaldi et al., 2013), in the Cordevole River (Belluno, northeastern Italy), one of the main tributaries of the Piave River. The first phase of the MQI procedure (general setting and segmentation) was implemented for the whole catchment area, and remote sensing and GIS techniques have been used to detect and classify the 132 segments between the $6^{\text {th }}$ and $4^{\text {th }}$ order (Horton-Strahler classification; Strahler, 1964). The 28 indicators contained in the evaluation forms were applied in the second phase for 42 reaches (i.e. approx. $32 \%$ of the total river network). In addition, we propose a methodology for a semi-automatic calculation of lateral confinement (defined by Degree of Confinement and a Confinement Index) in order to reduce the period of time required for river network segmentation. Part of the GIS analyses, and in particular the field surveys, were developed as part of two Bachelor degree theses (Zorzi, 2013; Loreggian, 2013).

\section{Materials and methods}

\section{Study area}

The Cordevole River (Figure 1) is approximately $79 \mathrm{~km}$ long and runs for its entirety in the Province of Belluno (northeastern Italy). It rises from the Pordoi pass (1919 $\mathrm{m}$ asl) in the municipality of Livinallongo del Col di Lana, and it flows into the Piave river near the town of Mel, (275 $\mathrm{m}$ asl). Its main tributaries are the Fiorentina and Pettorina (near the village of Caprile), the Biois (near Cencenighe), and the Tegnas (near Taibon). Downstream of Agordo, the stream continues along a narrow valley where the water flow decreases considerably, due to the derivations created for hydroelectric production. A few kilometers from its confluence in the Piave River, it receives the Mis stream.

The catchment area (Figure 1), which accounts for $843 \mathrm{~km}^{2}$ (see the hydro GIS analysis below) is made up of mountainous terrain and this creates a hydrographical network with a complex morphology typical of Alpine basins. The hydrographical network extends for approximately $1440 \mathrm{~km}$ (calculated by ArcGIS, setting a minimum drainage area of $160,000 \mathrm{~m}^{2}$ ) with a drainage ratio of $1.7 \mathrm{~m}^{-1}$. Woodlands cover approximately $40 \%$ of the territory, most of which is occupied by spruce trees, and the local climate is influenced by altitude and exposure (mean annual temperature is approx. $7^{\circ} \mathrm{C}$ and mean annual precipitation is approx. $1100 \mathrm{~mm}$ ).

The geology of the area is very complex. The higher parts of the basin are generally composed of dolomite, limestone, and volcanic rocks forming subvertical cliffs, whereas the lower slopes, deeply incised by rivers, are formed by highly erodible sedimentary rocks and quaternary deposits, with diffuse mass wasting processes (Picco et al., 2012).

The flow regime is characterised by a high runoff during the snowmelt period (May-June) with also significant summer storms, and low flows during the coldest months (January-February). In autumn, intense rainfall of short duration is common and subsequent flash floods are frequent events. Part of the basin lies within the Belluno
Dolomites National Park and there are several areas of Regional interest and natural beauty.

Intervention has led to the construction of artificial infrastructures in the stream (e.g. check-dams, transversal structures, bank protections) (Figure 2) and these are often located near villages and roads. Many of these were built in the years following the 1966 flood that showed just how dangerous these areas can be (for further information see Castiglioni, 1974; Malaguzzi et al., 2006). Cross structures, such as the check-dams, are currently filled with sediment, and are, therefore, no longer functional. In recent years, there has been a tendency to apply methods taken from river restoration engineering, but overall, there has been little human intervention and infrastructures have only been built in cases of extreme necessity to respond to problems of hydrogeological safety. The infrastructure constructed for hydroelectric power production, already designed in 1930 with the presence of two natural basins (Marmolada Glacier and Alleghe Lake) (Figure 2B), are mainly represented by the Masarè spillway (Alleghe), the Ghirlo dam (Cenceninghe) and the $91 \mathrm{~m}$ high Mis dam (Figure 2C).

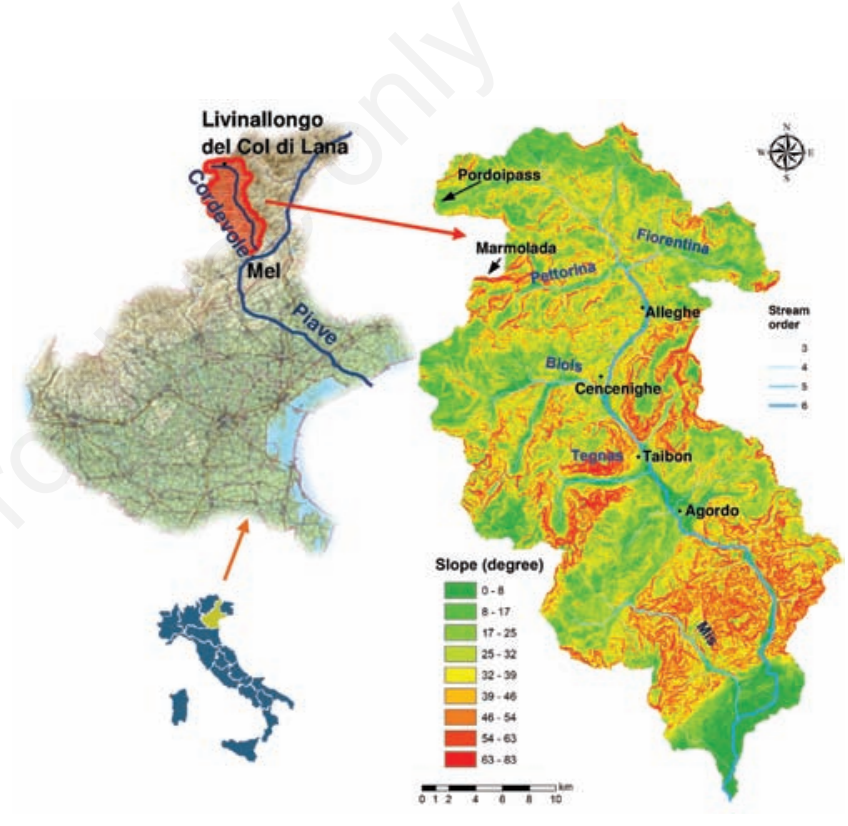

Figure 1. Map of the Cordevole river basin, stream order and slope.

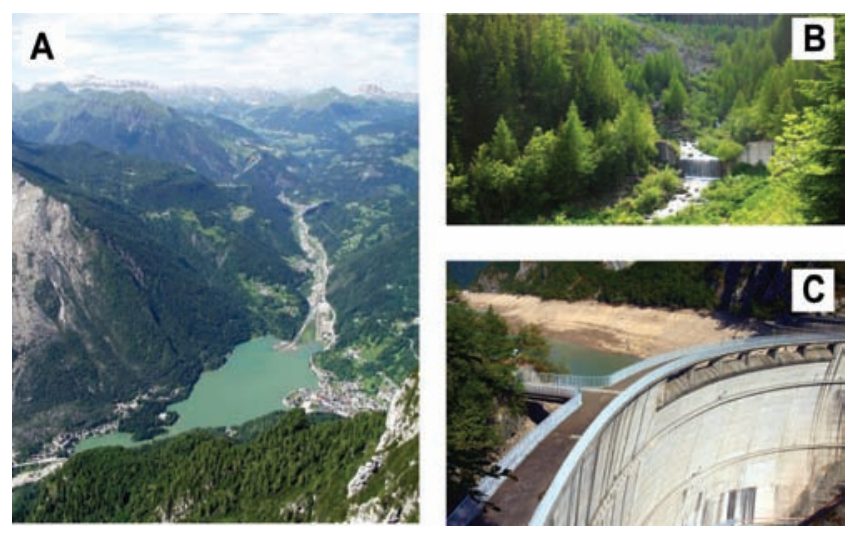

Figure 2. The study area. A) Alleghe Lake and Cordevole river. B) Check-dam in the upper part of the Cordevole river. C) Mis Dam. 


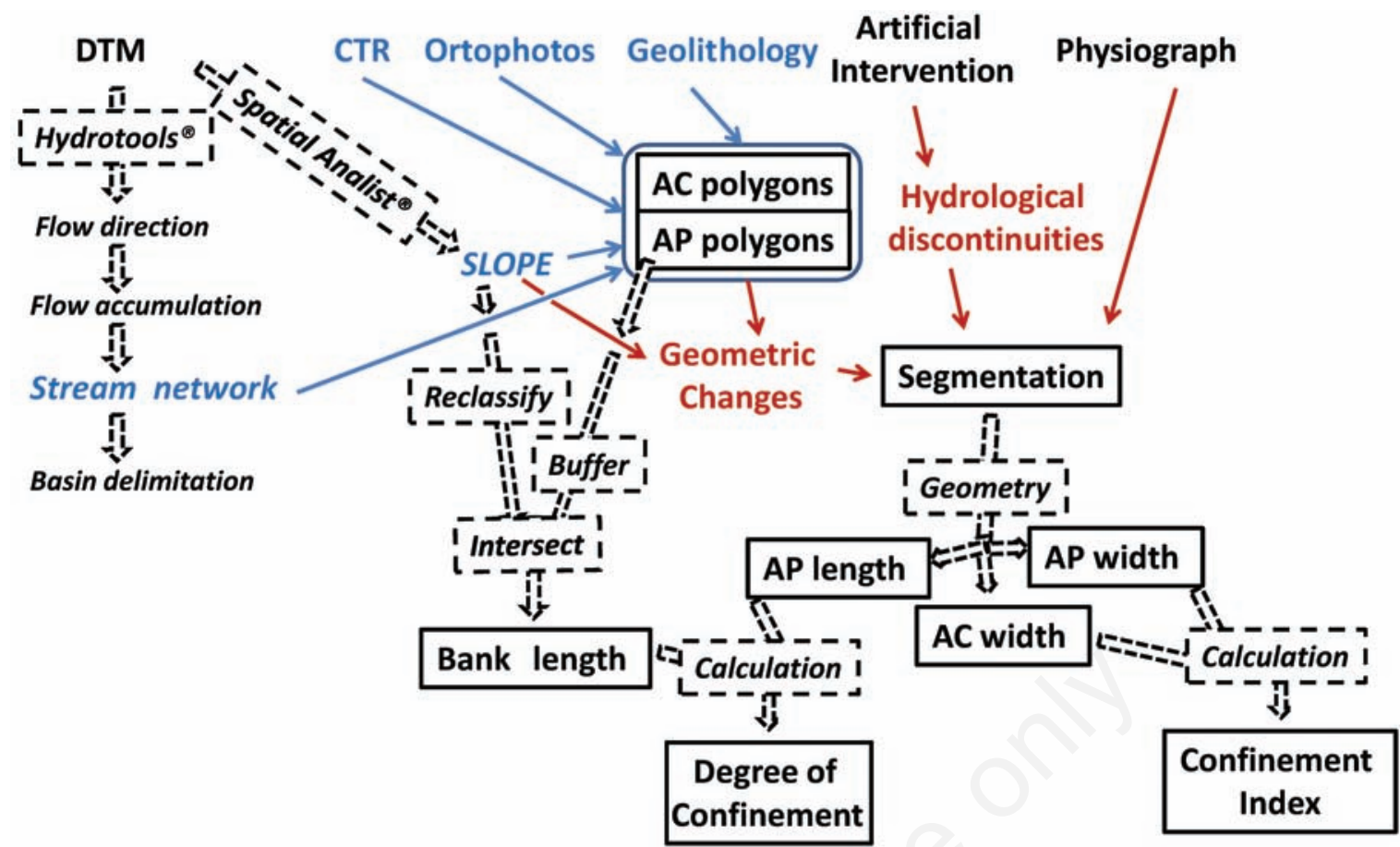

Figure 3. Flowchart that describe the procedure of semi-automated GIS model for segmentation and calculation of parameters. Data souces are on top line. Automated processes have been highlighted with dotted boxes. See text for description. AP, alluvial plain; AC, active channel.

\section{Methods}

IDRAIM is a method of analysing and monitoring hydromorphological alteration that was created to support river management through the integration of environmental quality objectives and risk mitigation. It consists of two indexes: i) the alteration of the hydrological regime index (IARI); and ii) the MQI that defines stream morphological quality. The MQI procedure (Rinaldi et al., 2012) is made up of three phases: i) general setting and segmentation; ii) evaluation of the current morphological condition of river reaches in terms of functionality, artificiality, and recent channel changes; iii) monitoring of the morphological quality variation. The evaluation of the current morphological condition and deviation from the reference state is performed by applying a set of 28 indicators that assess the continuity of river processes, channel morphological conditions, and riparian vegetation. The reference state is represented by a river reach in dynamic equilibrium with undisturbed geomorphic processes, and where the artificiality does not significantly change the dynamics of the river, allowing it to perform its expected morphological functions (Rinaldi et al., 2013). The methods of investigation are characterised by an integrated approach to perform remote sensing analyses and field surveys, with sufficiently large spatial and temporal scales in relation to the various aspects analysed (e.g. longitudinal continuity).

During the river network segmentation, various tools and scripts were used to reduce the application time, e.g. semi-automatic calculation of the indexes needed to define the degree of confinement. The second phase consists in the analysis of the information collected from the first phase and the MQI evaluation. Moreover, in this phase, 42 reaches were investigated by field surveys, with the support of the evaluation forms, in order to define the geomorphic functionality, artificiality and channel adjustments for each reach.
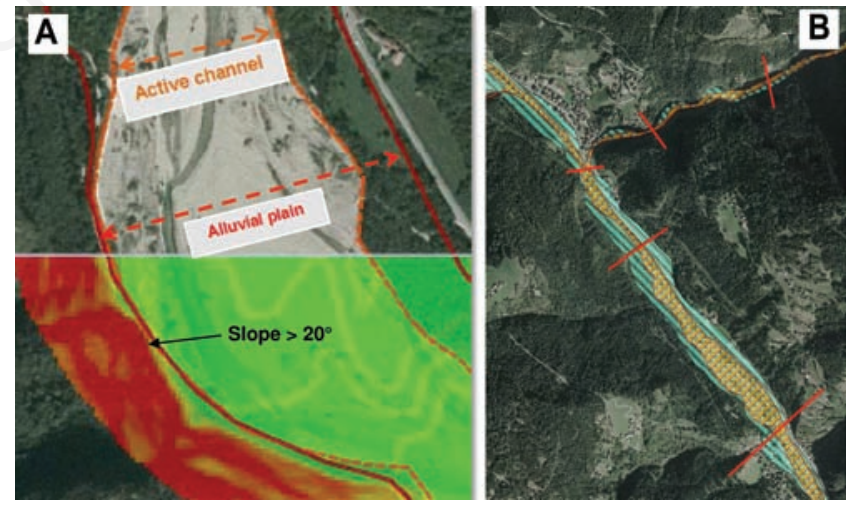

Figure 4. Calculation of confinement indexes (A); profiling of the active channel and alluvial plain, and segmentation (B).
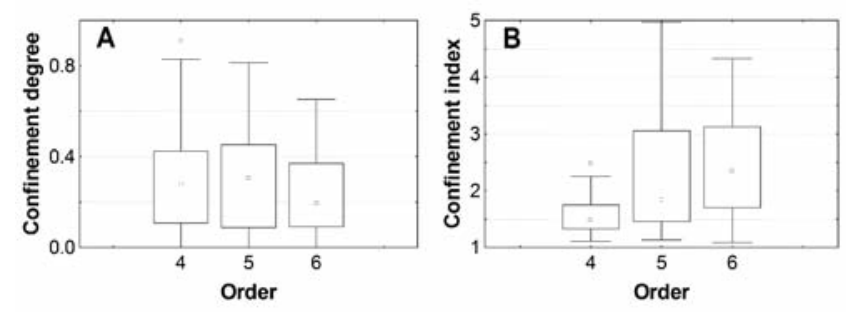

Figure 5. Degree (A) and confinement index (B) in relation to order of the 132 reaches identified through the segmentation phase of morphological quality index protocol. The square within each box indicates the median value, box ends are $25^{\text {th }}$ and $75^{\text {th }}$ percentiles, whiskers are the non-outlier extreme. 
Table 1. Characteristics of the $4^{\text {th }}$ order reaches obtained in the segmentation phase of morphological quality index protocol. The last row shows the average values.

\begin{tabular}{|c|c|c|c|c|c|c|c|c|c|c|}
\hline Reach ID & $\begin{array}{l}\text { Stream } \\
\text { name }\end{array}$ & $\begin{array}{c}\text { Stream } \\
\text { order }\end{array}$ & $\begin{array}{l}\text { Length } \\
\text { (m) }\end{array}$ & $\begin{array}{l}\text { Me } \\
\text { wi } \\
\text { Alluvial } \\
\text { plain } \\
\text { (m) }\end{array}$ & $\begin{array}{l}\text { ean } \\
\text { dth } \\
\text { Active } \\
\text { channel } \\
\text { (m) }\end{array}$ & $\begin{array}{l}\text { Mean } \\
\text { elevation } \\
\text { (m asl) }\end{array}$ & $\begin{array}{l}\text { Degree of } \\
\text { confinement }\end{array}$ & $\begin{array}{l}\text { Confinement } \\
\text { index }\end{array}$ & $\begin{array}{c}\text { Mean } \\
\text { channel } \\
\text { slope }(\mathrm{m} / \mathrm{m})\end{array}$ & $\begin{array}{c}\text { Drainage } \\
\text { area } \\
\left(\mathrm{km}^{2}\right)\end{array}$ \\
\hline 40144 & Cordevole & 4 & 742 & 40 & 18 & 1131 & 0.40 & 2.22 & 0.03 & 70.2 \\
\hline 40145 & Cordevole & 4 & 1270 & 19 & 11 & 1164 & 0.66 & 1.73 & 0.03 & 68.8 \\
\hline 40146 & Cordevole & 4 & 1046 & 19 & 12 & 1203 & 0.23 & 1.58 & 0.04 & 66.3 \\
\hline 40147 & Cordevole & 4 & 1375 & 30 & 21 & 1255 & 0.22 & 1.43 & 0.05 & 56.3 \\
\hline 40148 & Cordevole & 4 & 1181 & 20 & 12 & 1312 & 0.17 & 1.67 & 0.04 & 46.5 \\
\hline 40149 & Cordevole & 4 & 1098 & 11 & 9 & 1433 & 0.68 & 1.22 & 0.18 & 14.8 \\
\hline 40150 & Cordevole & 4 & 619 & 28 & 15 & 1582 & 0.22 & 1.87 & 0.16 & 9.8 \\
\hline 40211 & Mis & 4 & 1282 & 29 & 20 & 700 & 0.35 & 1.45 & 0.04 & 31.4 \\
\hline 40212 & Mis & 4 & 877 & 28 & 25 & 752 & 0.69 & 1.12 & 0.06 & 15.5 \\
\hline 40213 & Mis & 4 & 1536 & 18 & 15 & 877 & 0.53 & 1.20 & 0.13 & 10.8 \\
\hline 40301 & Tegnas & 4 & 1262 & 72 & 48 & 906 & 0.35 & 1.50 & 0.10 & 21.5 \\
\hline 40302 & Tegnas & 4 & 1625 & 33 & 20 & 984 & 0.49 & 1.65 & 0.02 & 17.2 \\
\hline 40401 & Biois & 4 & 1826 & 25 & 13 & 1077 & 0.19 & 1.92 & 0.05 & 53.7 \\
\hline 40402 & Biois & 4 & 1840 & 40 & 20 & 1158 & 0.03 & 2.00 & 0.04 & 44.3 \\
\hline 40501 & Fiorentina & 4 & 1750 & 22 & 15 & 1210 & 0.19 & 1.47 & 0.07 & 38.2 \\
\hline 40502 & Fiorentina & 4 & 1150 & 40 & 28 & 1321 & 0.28 & 1.43 & 0.08 & 27.4 \\
\hline 40503 & Fiorentina & 4 & 1257 & 22 & 17 & 1396 & 0.28 & 1.29 & 0.05 & 24.2 \\
\hline 40504 & Fiorentina & 4 & 1063 & 19 & 13 & 1466 & 0.19 & 1.46 & 0.08 & 14.0 \\
\hline 40505 & Fiorentina & 4 & 1259 & 15 & 12 & 1536 & 0.05 & 1.25 & 0.05 & 10.3 \\
\hline 40601 & Pettorina & 4 & 978 & 23 & 16 & 1027 & 0.12 & 1.44 & 0.05 & 52.5 \\
\hline 40602 & Pettorina & 4 & 826 & 28 & 19 & 1066 & 0.04 & 1.47 & 0.04 & 49.8 \\
\hline 40603 & Pettorina & 4 & 690 & 27 & 16 & 1106 & 0.30 & 1.69 & 0.07 & 47.8 \\
\hline 40604 & Pettorina & 4 & 795 & 13 & 9 & 1162 & 0.25 & 1.44 & 0.08 & 46.2 \\
\hline 40605 & Pettorina & 4 & 1477 & 17 & 10 & 1218 & 0.02 & 1.70 & 0.03 & 43.5 \\
\hline 40606 & Pettorina & 4 & 612 & 8 & 6 & 1258 & 0.23 & 1.33 & 0.05 & 37.4 \\
\hline 40607 & Pettorina & 4 & 1507 & 16 & 10 & 1350 & 0.62 & 1.60 & 0.10 & 32.4 \\
\hline 40608 & Pettorina & 4 & 1907 & 9 & 7 & 1488 & 0.05 & 1.29 & 0.07 & 27.1 \\
\hline 40701 & Codalunga & 4 & 1282 & 20 & 18 & 1224 & 0.47 & 1.11 & 0.12 & 13.5 \\
\hline 40702 & Codalunga & 4 & 910 & 35 & 21 & 1351 & 0.25 & 1.67 & 0.11 & 12.5 \\
\hline 40703 & Codalunga & 4 & 965 & 23 & 14 & 1475 & 0.28 & 1.64 & 0.15 & 10.4 \\
\hline 40801 & Bordina & 4 & 1486 & 18 & 8 & 998 & 0.63 & 2.25 & 0.20 & 11.4 \\
\hline 40901 & Sarzana & 4 & 1180 & 39 & 20 & 622 & 0.49 & 1.95 & 0.09 & 25.2 \\
\hline 40902 & Sarzana & 4 & 1124 & 23 & 16 & 751 & 0.65 & 1.44 & 0.14 & 24.0 \\
\hline 40903 & Sarzana & 4 & 1515 & 18 & 12 & 879 & 0.44 & 1.50 & 0.07 & 19.5 \\
\hline 40904 & Sarzana & 4 & 1187 & 11 & 9 & 983 & 0.65 & 1.22 & 0.09 & 16.7 \\
\hline 41001 & Rova & 4 & 609 & 29 & 26 & 587 & 0.02 & 1.12 & 0.05 & 20.1 \\
\hline 41002 & Rova & 4 & 990 & 29 & 26 & 634 & 0.07 & 1.12 & 0.06 & 19.4 \\
\hline 41003 & Rova & 4 & 775 & 20 & 15 & 692 & 0.31 & 1.33 & 0.07 & 18.0 \\
\hline 41004 & Rova & 4 & 345 & 16 & 8 & 737 & 0.28 & 2.00 & 0.10 & 17.5 \\
\hline 41101 & Missiaga & 4 & 1816 & 25 & 10 & 640 & 0.25 & 2.50 & 0.08 & 23.9 \\
\hline 41201 & Liera & 4 & 1626 & 13 & 9 & 969 & 0.09 & 1.44 & 0.05 & 40.7 \\
\hline 41202 & Liera & 4 & 963 & 13 & 7 & 1039 & 0.02 & 1.86 & 0.06 & 37.7 \\
\hline 41203 & Liera & 4 & 813 & 13 & 10 & 1090 & 0.00 & 1.30 & 0.05 & 35.4 \\
\hline 41204 & Liera & 4 & 1020 & 23 & 12 & 1140 & 0.02 & 1.92 & 0.06 & 32.2 \\
\hline 41205 & Liera & 4 & 879 & 15 & 12 & 1206 & 0.00 & 1.25 & 0.08 & 27.5 \\
\hline 41206 & Liera & 4 & 950 & 20 & 14 & 1265 & 0.00 & 1.43 & 0.05 & 26.6 \\
\hline
\end{tabular}

Continue to next page. 


\section{General setting and segmentation}

The initial setting and river network segmentation into relatively homogeneous reaches was carried out as part of a geographical information systems (GIS) project (ArcGIS 10, ESRI ${ }^{\circledR}$ ). We considered the valley form, slope, flow and sediment load conditioning (Brierley and Fryirs, 2005) derived from analysis of the following metadata: i) digital colour orthophotos for the years 2000, 2003, and 2006 available in Web Map Service mode on the national Geoportal (http:/www.pcn.minambiente.it/GN/); ii) Digital Terrain Model (DTM) (ascii format) downloaded from the regional Geoportal (http://idt.regione.veneto.it/ app/metacatalog/index?deflevel=165) and subsequently converted to raster with a cell size of $5 \mathrm{~m}$; iii) regional technical maps (Carta Tecnica Regionale, Region of Veneto, from the regional Geoportal); iv) regional physiographical units map available from the website of the Agency for Environmental Protection and Prevention of Veneto (ARPAV) (http://www.arpa.veneto.it/temi-ambientali/suolo); v) regional geolithological map (down-loaded from the regional Geoportal); vi) artificial intervention database (watershed management and torrent control structures) of the Province of Belluno, provided by the Regional Hydrological Service.

These last metadata are organised according to types of structures, in different shaped files that report essential information (e.g. year of construction, geometric dimensions, etc.) both for the first and the second phase of the MQI evaluation.

Definition of the catchment area and the identification of the synthetic hydrographical network was made with the Arc Hydro Tools $\left(\mathrm{ESRI}^{\circledR}\right.$ ) setting the blue line threshold value to $160,000 \mathrm{~m}^{2}$. Slope and exposure maps were derived from the DTM. This geospatial information, together with the 2006 orthophotos, were used for photo-interpretation (Figure 3 ) and for editing the active channel and alluvial plain (which is defined as the maximum width of the river region under study). This editing was carried out throughout the river network from the $4^{\text {th }}$ to the $6^{\text {th }}$ order (Horton-Strahler classification; Strahler, 1964) because in the reaches located in the upper part of the basin, interpre- tation of the photographic material was problemactic due to the quality of DTM and images, and disturbance (see below).

The segmentation methodology was based on the MQI protocol application (Rinaldi et al., 2012), but has been applied following a slightly different step sequence for which some semi-automatic GIS processes were used. Figure 3 presents the simplified flow chart that summarises the GIS processing performed. Automated processes have been highlighted with dotted boxes. The alluvial plain and active channel editing was carried out following the validated stream network (hydrotools ${ }^{\circledR}$ ) detected by photo interpretation, but also taking into account the geolithology, slope and the CTR. A first segmentation (editing of lines) was then created considering the physiographical units, hydrological discontinuities (from hydrological elaboration and artificial intervention database), significant geometric changes, and variations in geolithology (Figure 4). The active channel and alluvial plain shapes

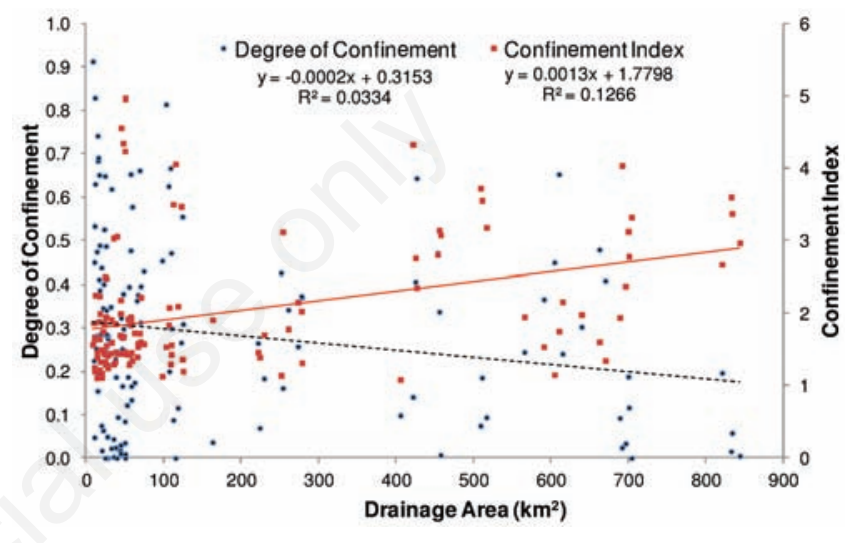

Figure 6. Degree and confinement index in relation to the drainage area.

Table 1. Continued from previous page.

\begin{tabular}{|c|c|c|c|c|c|c|c|c|c|c|}
\hline Reach ID & $\begin{array}{l}\text { Stream } \\
\text { name }\end{array}$ & $\begin{array}{l}\text { Stream } \\
\text { order }\end{array}$ & $\begin{array}{l}\text { Length } \\
\text { (m) }\end{array}$ & $\begin{array}{l}\text { Alluvic } \\
\text { plair } \\
\text { (m) }\end{array}$ & $\begin{array}{l}\text { th } \\
\text { Active } \\
\text { channel } \\
\text { (m) }\end{array}$ & $\begin{array}{l}\text { Mean } \\
\text { elevation } \\
\text { (m asl) }\end{array}$ & $\begin{array}{l}\text { Degree of } \\
\text { confinement }\end{array}$ & $\begin{array}{l}\text { Confinement } \\
\text { index }\end{array}$ & $\begin{array}{c}\text { Mean } \\
\text { channel } \\
\text { slope }(\mathrm{m} / \mathrm{m})\end{array}$ & $\begin{array}{c}\text { Drainage } \\
\text { area } \\
\left(\mathrm{km}^{2}\right)\end{array}$ \\
\hline 41207 & Liera & 4 & 525 & 20 & 15 & 1307 & 0.00 & 1.33 & 0.06 & 24.2 \\
\hline 41208 & Liera & 4 & 563 & 28 & 16 & 1327 & 0.06 & 1.75 & 0.01 & 21.7 \\
\hline 41209 & Liera & 4 & 1176 & 20 & 17 & 1482 & 0.29 & 1.18 & 0.26 & 20.1 \\
\hline 41210 & Liera & 4 & 1610 & 67 & 48 & 1727 & 0.28 & 1.40 & 0.11 & 13.9 \\
\hline 41401 & Nottole & 4 & 924 & 15 & 9 & 861 & 0.45 & 1.67 & 0.11 & 10.3 \\
\hline 41501 & Listolade & 4 & 1391 & 67 & 27 & 747 & 0.34 & 2.48 & 0.11 & 25.4 \\
\hline 41502 & Listolade & 4 & 1565 & 69 & 37 & 934 & 0.53 & 1.86 & 0.14 & 23.0 \\
\hline 41503 & Listolade & 4 & 1494 & 56 & 25 & 1162 & 0.39 & 2.24 & 0.16 & 17.2 \\
\hline 41601 & No name & 4 & 1189 & 11 & 7 & 544 & 0.91 & 1.57 & 0.20 & 8.4 \\
\hline 41701 & No name & 4 & 1361 & 27 & 12 & 773 & 0.74 & 2.25 & 0.17 & 14.5 \\
\hline 41801 & Caiada & 4 & 651 & 6 & 5 & 1064 & 0.83 & 1.20 & 0.08 & 11.1 \\
\hline 41901 & Andraz & 4 & 1246 & 17 & 12 & 1178 & 0.28 & 1.42 & 0.10 & 27.2 \\
\hline 41902 & Andraz & 4 & 1093 & 14 & 9 & 1308 & 0.29 & 1.56 & 0.13 & 25.7 \\
\hline 41903 & Andraz & 4 & 606 & 16 & 11 & 1421 & 0.40 & 1.45 & 0.14 & 22.4 \\
\hline 41904 & Andraz & 4 & 1298 & 17 & 9 & 1544 & 0.41 & 1.89 & 0.12 & 16.4 \\
\hline 41905 & Andraz & 4 & 541 & 18 & 8 & 1655 & 0.15 & 2.25 & 0.11 & 14.5 \\
\hline \multicolumn{2}{|c|}{62 Reaches } & Mean & 1147 & 25 & 16 & 1111 & 0.31 & 1.59 & 0.09 & 28 \\
\hline
\end{tabular}


have been subdivided into various polygons with the segmentation line intersection (Figure 4). The outer area alluvial plain polygons (buffer $20 \mathrm{~m}$ ) was intersected with the slope map, and the percentage of banks directly in contact with the hill-slopes was calculated automatically (identified as the terrain portions with a slope greater than $20^{\circ}$ ) (Figures 3A and Figure 4A). The Degree of Confinement has been defined for each reach. Other automatic processes were used to calculate the geometry of each polygon from which it was possible to evaluate the relationship between the alluvial plain and the active channel width (Figure 4A) (Confinement Index) (Zorzi, 2013). The lateral confinement could be computed by putting together these two indexes (for more details see Rinaldi et al., 2012, 2013). According to this lateral confinement, appropriate adjustments were then calculated on the initial division. The river morphology was then defined, taking into account the specific Italian Alpine context (Lenzi et al., 2000).

\section{Evaluation procedure}

After the segmentation phase, the data and information needed to apply the evaluation procedure were summarised for each reach identified. The field surveys were carried out in the period August 2012-May 2013 and the evaluation forms were also used. Of the 42 reaches analysed, 31 are located in the upper part of the Cordevole catchment

Table 2. Characteristics of the $5^{\text {th }}$ order reaches obtained in the segmentation phase of morphological quality index protocol. The last row shows the average values.

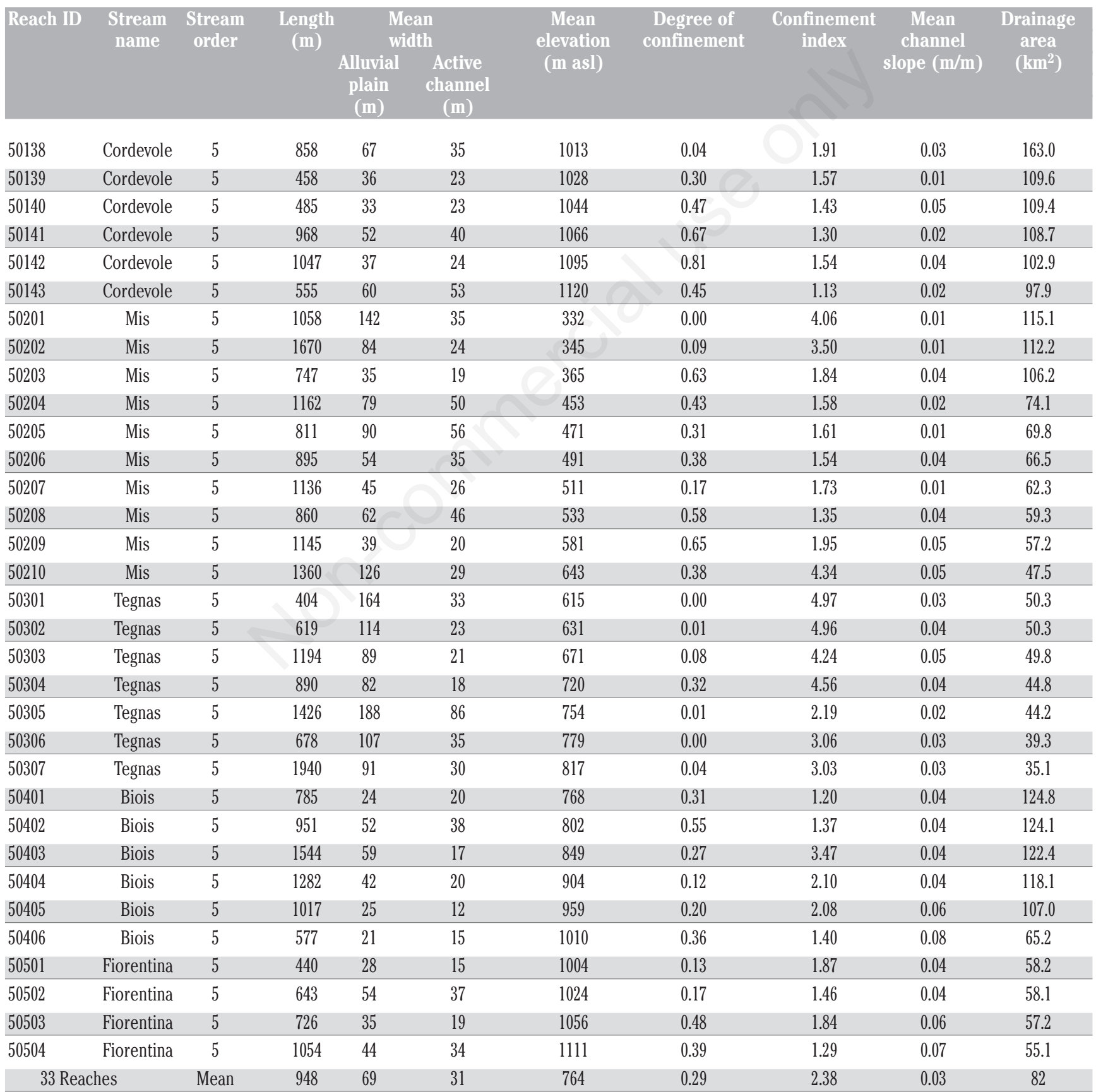


(76\% of reaches identified in the segmentation phase) while the 11 other reaches are representative of the downstream area. The water conditions while measurements were being taken were characterised by low flow rates with no significant floods reported in the periods previous to the study.

As required by the protocol, different indexes of geomorphological functionality, artificiality, and channel adjustments were analysed.
Channel adjustments were investigated only for two reaches that have a channel width over $30 \mathrm{~m}$. The evaluation of the 28 indicators was completed with the application of two types of MQI evaluation forms: i) one for confined channels; and ii) one for semi-confined and unconfined channels (Rinaldi et al., 2013). These two types of evaluation forms have different numbers and types of indicators.

Most attention was paid to the analysis of the continuity (lateral and

Table 3. Characteristics of the $6^{\text {th }}$ order reaches obtained in the segmentation phase of morphological quality index protocol. The last row shows the average values.

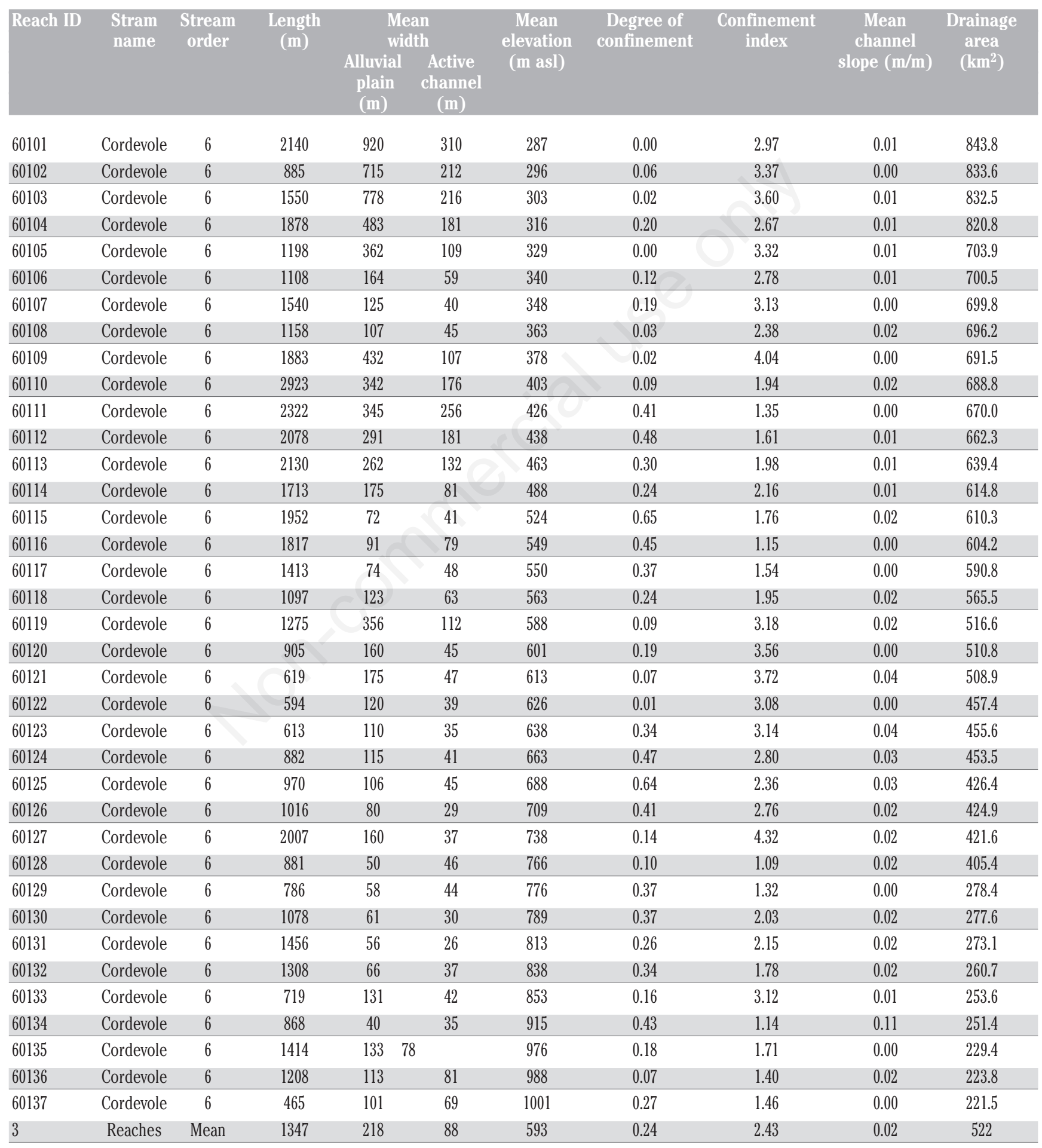


longitudinal) of river processes, channel morphological conditions, and vegetation. Most of the applied indexes were evaluated from the information obtained during the first phase of general settings and segmentation. Three classes are generally defined for each indicator, with a score of 0 in the case of absence or negligible presence of alteration, 23 for intermediate alteration, and 5-6 the highest alteration score. In cases of an extremely dense and dominant presence of artificial elements, additional points of alteration are assigned. The final score is calculated as the ratio between total deviation from non-altered conditions (assigned to all indicators applied in the reach) and the maximum possible deviation for the given stream typology. Following this logic, the morphological alteration index (MAI), with values ranging from 0 to 1 , was calculated. MQI is complementary to MAI (MQI=1$\mathrm{MAI}$ ). It is also possible to calculate the sub-vertical score of functionality $\left(\mathrm{MQI}_{\mathrm{F}}\right)$, artificiality $\left(\mathrm{MQI}_{\mathrm{A}}\right)$ and channel variation $\left(\mathrm{MQI}_{\mathrm{V}}\right)$ in order to identify the critical points of the reaches analysed.

\section{Results}

\section{Segmentation}

The segmentation phase has identified 62 reaches of $4^{\text {th }}, 33$ of $5^{\text {th }}$, and 37 of $6^{\text {th }}$ orders. For each of them, the average values of the following parameters were calculated in a GIS environment:
- segment length (m);

- width of the active channel (m);

- width of the alluvial plain (m);

- mean elevation ( $\mathrm{m}$ asl);

- Degree of Confinement (methodology as above);

- Confinement Index (methodology as above);

- average channel slope derived from the DTM $(\mathrm{m} / \mathrm{m})$;

- drainage area at the outlet of the reach from hydrological analysis $\left(\mathrm{km}^{2}\right)$.

All data were included in a GIS project database and parameters for the reaches of the Cordevole River are reported in Table 1 (reaches of $4^{\text {th }}$ order), Table 2 (reaches of $5^{\text {th }}$ order), and Table 3 (reaches of the $6^{\text {th }}$ order).

The results show that the average length of the obtained river segments ranges from $948 \mathrm{~m}$ ( $5^{\text {th }}$ order $)$ to $1347 \mathrm{~m}$ ( $6^{\text {th }}$ order $)$. The average length of reaches of $4^{\text {th }}$ order are $(1147 \mathrm{~m})$ slightly higher than that relating to the $5^{\text {th }}$ order reaches. This may be affected by the presence of large areas with homogeneous morphological and physiographical characteristics. The average width of the active channel is strictly linked to the reach order and changes from $16 \mathrm{~m}$ (4th order), to $31 \mathrm{~m}$ ( $5^{\text {th }}$ order) and $88 \mathrm{~m}$ for the reach of $6^{\text {th }}$ order, as is the average widths reported for the floodplain of $25 \mathrm{~m}, 69 \mathrm{~m}$ and $218 \mathrm{~m}$, respectively. Near the confluence with the Piave, the Cordevole River greatly increases in size with a fluvial plain of approx. $920 \mathrm{~m}$ (reach 60101) (Table 3). The average slope shows values ranging from $0.02 \mathrm{~m} / \mathrm{m}$ ( $6^{\text {th }}$ order) to 0.09 ( $4^{\text {th }}$ order) with a maximum of 0.26 in the Liera stream (reach 41209 )

Table 4. Morphological quality index results for the 42 reaches analyzed. Contains the name of the river, reach order, the class of confinement, morphological quality index of functionality, morphological quality index of alteration, and morphological alteration index (see Figure 7 for the distribution into the river network of morphological quality class evaluated).

\begin{tabular}{|c|c|c|c|c|c|c|c|c|c|c|c|c|c|c|}
\hline ID & 60102 & 60103 & 60119 & 60120 & 60124 & 60133 & 60134 & 60135 & 60136 & 60137 & 50138 & 50139 & 50140 & 50141 \\
\hline Collector & Cord & Cord & Cord & Cord & Cord & Cord & Cord & Cord & Cord & Cord & Cord & Cord & Cord & Cord \\
\hline Order & 6 & 6 & 6 & 6 & 6 & 6 & 6 & 6 & 6 & 6 & 5 & 5 & 5 & 5 \\
\hline Conf. class & S-NC & S-NC & S-NC & S-NC & S-NC & S-NC & C & S-NC & S-NC & $\mathrm{C}$ & S-NC & S-NC & $\mathrm{C}$ & $\mathrm{C}$ \\
\hline $\mathrm{MQI}_{\mathrm{F}}$ & 0.74 & 0.86 & 0.19 & 0.44 & 0.81 & 0.74 & 0.76 & 0.47 & 0.51 & 0.78 & 0.58 & 0.35 & 0.70 & 0.86 \\
\hline $\mathrm{MQI}_{\mathrm{A}}$ & 0.71 & 0.80 & 0.36 & 0.58 & 0.85 & 0.68 & 0.19 & 0.71 & 0.80 & 0.72 & 0.59 & 0.56 & 0.79 & 0.79 \\
\hline MAI & 0.26 & 0.17 & 0.63 & 0.43 & 0.17 & 0.30 & 0.52 & 0.38 & 0.32 & 0.27 & 0.38 & 0.47 & 0.27 & 0.17 \\
\hline MQI & $0.74^{*}$ & $0.83^{*}$ & $0.37^{\circ}$ & $0.57^{\#}$ & $0.83^{*}$ & $0.70^{*}$ & $0.48^{\circ}$ & $0.62^{\#}$ & $0.68^{\#}$ & $0.73^{*}$ & $0.62^{\#}$ & $0.53^{\#}$ & $0.73^{*}$ & $0.83^{*}$ \\
\hline ID & 50142 & 50143 & 40144 & 40145 & 40146 & 40147 & 40148 & 50201 & 50202 & 50203 & 50204 & 50501 & 50502 & 50503 \\
\hline Collector & Cord & Cord & Cord & Cord & Cord & Cord & Cord & Mis & Mis & Mis & Mis & Fior & Fior & Fior \\
\hline Order & 5 & 5 & 4 & 4 & 4 & 4 & 4 & 5 & 5 & 5 & 5 & 5 & 5 & 5 \\
\hline Conf. class & C & C & S-NC & C & C & $\mathrm{C}$ & C & S-NC & S-NC & S-NC & S-NC & S-NC & C & $\mathrm{C}$ \\
\hline $\mathrm{MQI}_{\mathrm{F}}$ & 1.00 & 0.84 & 0.81 & 0.92 & 0.78 & 0.78 & 0.86 & 0.84 & 0.35 & 0.77 & 0.93 & 0.49 & 0.65 & 0.65 \\
\hline$M Q I_{A}$ & 1.00 & 0.89 & 0.86 & 0.96 & 0.79 & 0.75 & 0.93 & 0.73 & 0.59 & 0.56 & 0.77 & 0.51 & 0.60 & 0.58 \\
\hline MAI & 0.00 & 0.12 & 0.16 & 0.05 & 0.25 & 0.25 & 0.11 & 0.22 & 0.46 & 0.33 & 0.17 & 0.49 & 0.41 & 0.44 \\
\hline MQI & $1.00^{\S}$ & $0.88^{\S}$ & $0.84^{*}$ & $0.96^{\S}$ & $0.76^{*}$ & $0.75^{*}$ & $0.89^{\S}$ & $0.78^{*}$ & $0.54^{\#}$ & $0.67^{\#}$ & $0.83^{*}$ & $0.51^{\#}$ & $0.59^{\#}$ & $0.56^{\#}$ \\
\hline ID & 50504 & 40501 & 40502 & 40503 & 40504 & 40505 & 40601 & 40602 & 40603 & 40604 & 40605 & 40606 & 40607 & 40608 \\
\hline Collector & Fior & Fior & Fior & Fior & Fior & Fior & Pett & Pett & Pett & Pett & Pett & Pett & Pett & Pett \\
\hline Order & 5 & 4 & 4 & 4 & 4 & 4 & 4 & 4 & 4 & 4 & 4 & 4 & 4 & 4 \\
\hline Conf. class & $\mathrm{C}$ & $\mathrm{C}$ & $\mathrm{C}$ & $\mathrm{C}$ & $\mathrm{C}$ & S-NC & $\mathrm{C}$ & $\mathrm{C}$ & $\mathrm{C}$ & $\mathrm{C}$ & S-NC & $\mathrm{C}$ & $\mathrm{C}$ & $\mathrm{C}$ \\
\hline $\mathrm{MQI}_{\mathrm{F}}$ & 0.72 & 0.68 & 0.84 & 0.76 & 0.84 & 0.93 & 0.35 & 0.46 & 1.00 & 0.46 & 0.42 & 0.41 & 0.70 & 0.73 \\
\hline $\mathrm{MQI}_{\mathrm{A}}$ & 0.62 & 0.61 & 0.75 & 0.67 & 0.96 & 0.91 & -0.02 & 0.49 & 0.75 & 0.46 & 0.63 & 0.44 & 0.65 & 0.51 \\
\hline MAI & 0.39 & 0.33 & 0.20 & 0.33 & 0.12 & 0.11 & 0.89 & 0.54 & 0.19 & 0.56 & 0.49 & 0.59 & 0.31 & 0.38 \\
\hline MQI & $0.61^{\#}$ & $0.67^{\#}$ & $0.80^{*}$ & $0.67^{\#}$ & $0.88^{\S}$ & $0.89^{\S}$ & $0.11^{\wedge}$ & $0.46^{\circ}$ & $0.81^{*}$ & $0.44^{\circ}$ & $0.51^{\#}$ & $0.41^{\circ}$ & $0.69^{\#}$ & $0.62^{\#}$ \\
\hline
\end{tabular}

Cord, Cordevole; Conf. class, class of confinement; S-NC, semi-confined/unconfined; C, confined; MQIF, morphological quality index of functionality; MQIA, morphological quality index of alteration; MAI, morphological alteration index; MQI, morphological quality index; Fior, Fiorentina; Pett, Pettorina. Quality class in MQI: *good; ${ }^{\circ}$ poor; "moderate; ${ }^{\circledR}$ very good; ${ }^{\wedge}$ very poor. 
(Table 1). The average drainage area is $28 \mathrm{~km}^{2}$ in the $4^{\text {th }}$ order reaches, $82 \mathrm{~km}^{2}$ in the $5^{\text {th }}$ order reaches, and $522 \mathrm{~km}^{2}$ in the $6^{\text {th }}$ order reaches. The Degree of Confinement, calculated with semi-automatic GIS methods, has a median value of $0.2-0.3$ with a maximum of 0.9 ( $90 \%$ of channel in contact with the slopes) in the smaller streams (Figure 5A). Figure 6 shows the relationship between the Degree of Confinement and the drainage area $\left(\mathrm{R}^{2}=0.0034\right)$. It shows that there is no correlation with the dimensions of the collectors. The Confinement Index (alluvial plain $v s$ bankfull width ratio) is, instead, directly proportional to the stream order, with median values of 1.5 in the $4^{\text {th }}$ order reaches, 1.8 in the $5^{\text {th }}$ order reaches, and 2.4 in the $6^{\text {th }}$ order reaches (Figure $5 \mathrm{~B})$, although higher values are to be found among $5^{\text {th }}$ order reaches. The relationship between the Confinement Index and the drainage area for each reach was found to be better than the previous one (Figure 6), even though values were relatively low $\left(\mathrm{R}^{2}=0.1266\right)$.

\section{Morphological quality index evaluation}

Filling in the MQI evaluation forms took approximately $3 \mathrm{~h}$ for each reach analysed, for a total of 15 days of work. Ten reaches of $6^{\text {th }}$ order ( $27 \%$ of reaches of this order identified in the segmentation phase), 14 of $5^{\text {th }}$ order $(42 \%)$, and 18 of $4^{\text {th }}$ order $(27 \%)$ were analysed. The results derived from the application of various indexes have been organised in the summary sheets (one for each reach) that contain tables with the general settings (location, confinement and morphology), scores attributed to each indicator, and the calculation of the MQI with the corresponding class quality. These data are summarised in Table 4 with the name of the river, reach order, the class of confinement, MAI, MQI, $\mathrm{MQI}_{\mathrm{F}}$ and $\mathrm{MQI}_{\mathrm{A}}$. The MQIs obtained were also used in the GIS database from which a layout summary was obtained (Figure 7) where the quality classes are shown in different colours for each reach analysed.

These results show that $48 \%$ of the reaches analysed are of a good or

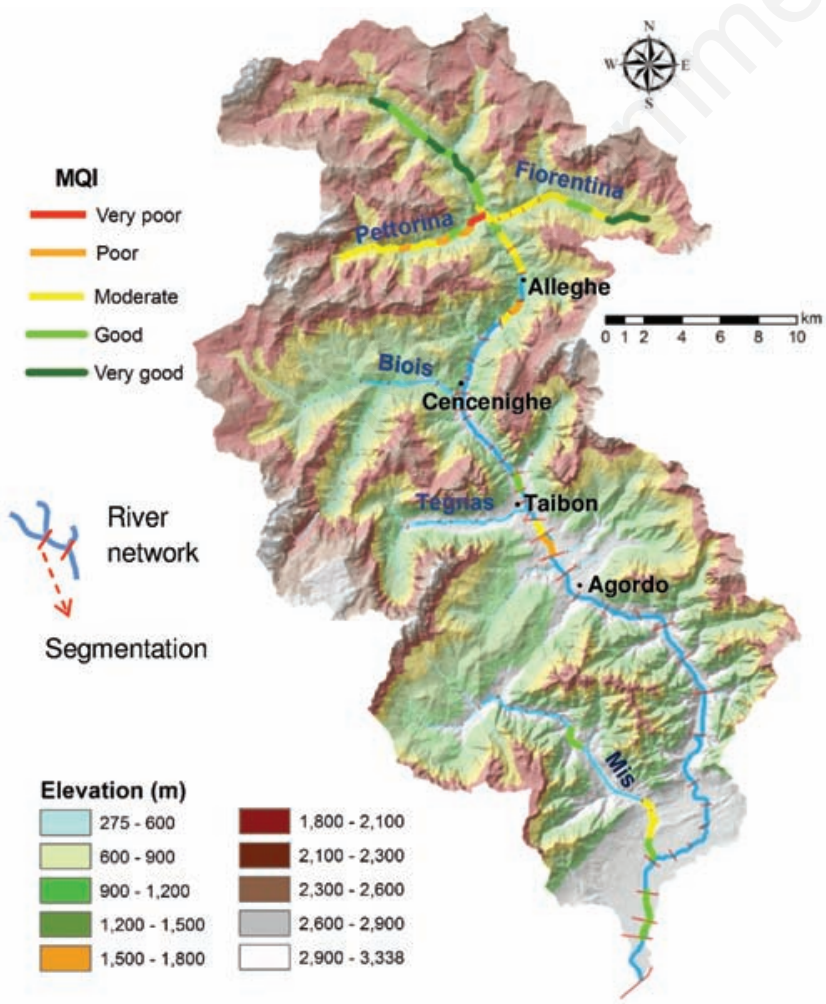

Figure 7. Elevation of Cordevole basin, hydrograph segmentation and morphological quality index evaluation results. high quality and these are mainly located in the High Cordevole or in the less hydrographical network (Figure 8A-D). Thirty-eight percent were of moderate quality, and, in particular, this concerned different reaches of the Fiorentina, Cordevole from Caprile to Alleghe and Pettorina (Figure 8E and F). Only 14\% are of poor or very poor quality, e.g. the Pettorina reach immediately upstream of the confluence with the Cordevole (Figure 8G and $\mathrm{H}$ ).

Careful examination of the sub-indexes (Table 4) shows that the reach with the worst quality (ID 40601) has a negative $\mathrm{MQI}_{\mathrm{A}}$ and this is due to the continuous presence of bank protections and check-dams in the reach that causes the assignation of additional scores in some indicators. The reach no. 60134 (Cordevole $6^{\text {th }}$ order) is heavily penalised for the same reason. Many other segments are affected by the presence of other artificial structures, e.g. the segment no. $50203\left(\mathrm{MQI}_{A}=0.56\right)$, where the Mis dam is located and no. $40608\left(\mathrm{MQI}_{A}=0.51\right)$, characterised by interventions for hydroelectric power production. In contrast, 19 of 42 reaches have a quality functionality index lower than the quality alteration index, e.g. segment no. $60119\left(\mathrm{MQI}_{\mathrm{F}}=0.19\right)$ and no. 50202 $(\mathrm{MQI}=0.35)$ which have a limited floodplain, poor variability of the section, and little presence or complete absence of functional vegetation in the fluvial corridor.

If we observe the MQI values obtained in the different collectors analysed (Figure 9A), we can see that the lowest median value is found

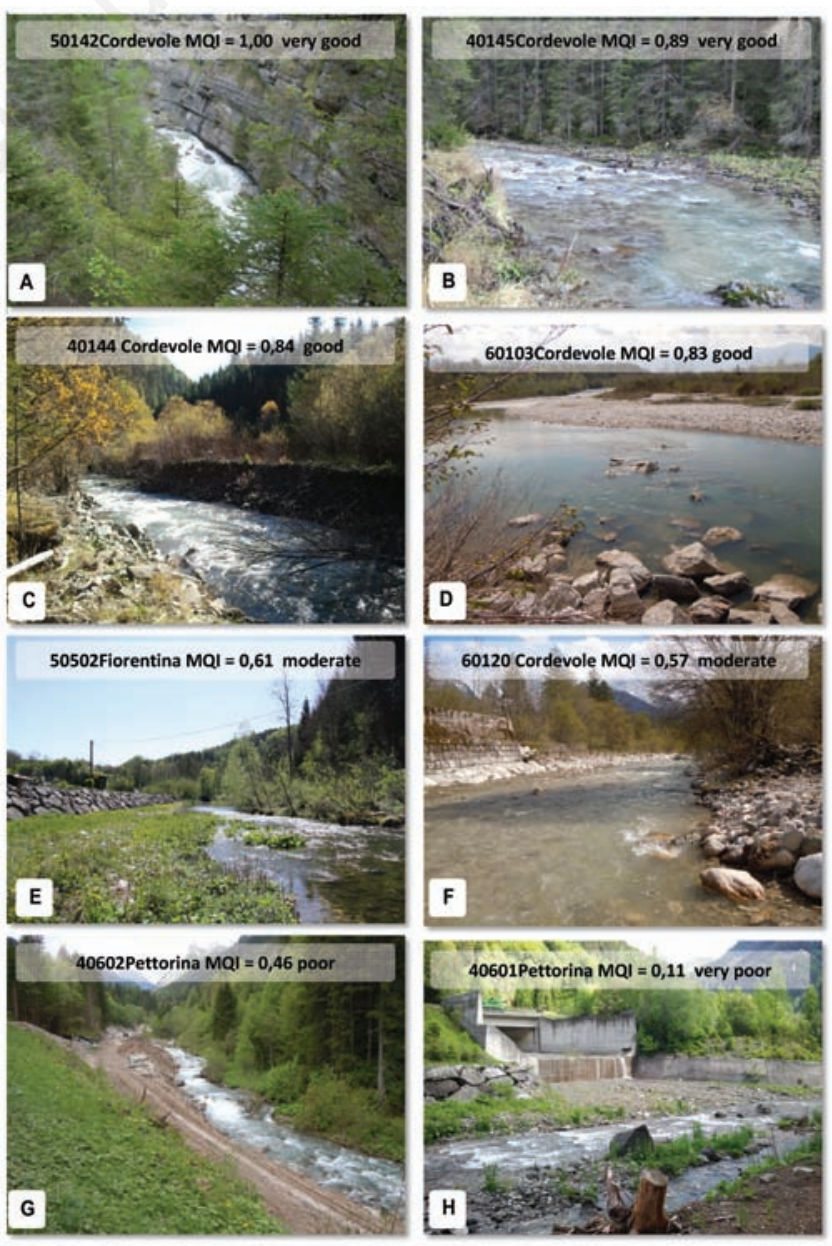

Figure 8. Some of the reaches evaluated and morphological quality index results. 

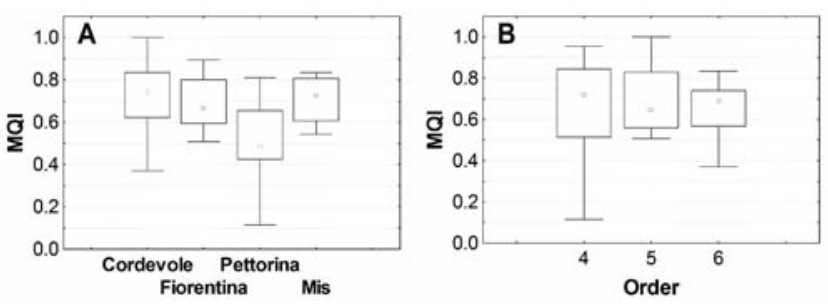

Figure 9. Morphological quality index evaluation results of the different streams (A) and in relation to order (B) for the 42 reaches analysed. The square within each box indicates the median value, box ends are $25^{\text {th }}$ and $75^{\text {th }}$ percentiles, whiskers are the non-outlier extreme.

for the Pettorina stream (0.49), followed by the Fiorentina $(0.67)$, the Mis (0.72) and then by the Cordevole (0.75), although in this last stream we have a very wide distribution of data (21 reaches analysed with MQI between 0.37 and 1). The distribution of morphological quality in relation to the stream order (Figure 9B) shows that the median value of $4^{\text {th }}$ order reaches is higher $(0.71)$, although in this category there are segments with the worst morphological characteristics. The $5^{\text {th }}$ order reaches have a median MQI of 0.64 while the $6^{\text {th }}$ order reaches have a median MQI of 0.69 .

\section{Discussion}

This paper shows the successful use in a Dolomite basin (Torrente Cordevole, Province of Belluno), of the new MQI protocol evaluation (Rinaldi et al., 2013). The use of some semi-automatic GIS tools has allowed us to greatly speed up the first phase of the general setting and segmentation. It was also possible to determine some indicators of alteration in the laboratory. We are currently planning to implement this methodology in an ArcGIS tool (through the model builder) also applicable to non-expert users in other areas. However, active channel and alluvial plain should always be edited manually. Some limitations or problems arising during this first phase were: i) the need for high standards of GIS analysis and editing; ii) the limitations of spatial analysis linked both to the quality of the DTM and images, and to the strong disturbance (shadows, vegetation, narrow valleys). In the case study analysed, the hydrographical network lower than the $4^{\text {th }}$ order are difficult to analyse; iii) the need for a complete and up-dated Artificial Intervention Database. Not all the artificial interventions are catalogued in this database. Also big infrastructure, such as the Mis dam (Figure 2C), are not included.

The second phase of indicator implementation has highlighted the non-availability of some information required for the evaluation, such as the management of artificial structures and river clearcut operations, as well as information regarding the morphometric changes of the last 50 years in the great reaches. Some indicators are extremely simplified, as shown by the MQI Authors (Rinaldi et al., 2013), and there is a strong subjectivity in the scoring of the indexes in relation to the experience and training of the operators. In order to accomodate this, the survey was carried out by a team of 3 researchers.

The sub-reaches that have the greatest degree of morphological alteration present: i) poor connectivity between hill-slopes and river corridor (mainly caused by the presence of roads) that is very important for the natural input of sediment and large wood from the slopes; ii) absence of vegetation in the river corridor due to human alteration, that is functional to a range of geomorphic processes; iii) presence of artificial elements, such as bed-load interception structures in the catchment, bank protection along the reach, and the removal of sediment, large wood and vegetation, already highlighted in Rigon et al. (2012a). The MQI has allowed us to assess the morphological condition for 42 reaches of the Cordevole Basin. In order to identify possible strategies of mitigation, we need to apply the MQI procedure to the entire water network, as required by the Protocol. However, partial restoration of the reaches with lower $\mathrm{MQI}$ values could be achieved by converting the old interception structures in new constructions designed by the criteria of river restoration engineering. In addition, it would be desirable to carry out an analysis of priorities, and implement intervention only where really necessary, possibly with low-impact structures such as wood retention structures with rope nets or rakes.

\section{References}

Brierley G.J., Fryirs K.A. 2005. Geomorphology and river management: applications of the river style framework. Blackwell, Oxford, UK.

Castiglioni G.B. 1974. Le calamità naturali nelle Alpi. Proc. XXI Congresso Geografico Italiano, Istituto di Geografia, Università di Padova, Italy.

Cencetti C., De Rosa P., Fredduzzi A. 2010. L'indice di qualità morfologica (IQM) dei corsi d'acqua: applicazione del metodo di valutazione al F. Chiani (Italia centrale). In: Atti $14^{\circ}$ Conf. Naz. ASITA (Brescia, 9-12 novembre 2010), Italy, pp 553-559.

European Commission, 2000. Directive 2000/60/EC of the European Parliament and of the Council of 23 October 2000 establishing a framework for community action in the field of water policy. Official Journal L 327, 22/12/2000, p 73.

European Commission, 2007. Directive 2007/60/EC of the European Parliament and of the Council of 23 October 2007 on the assessment and management of flood risks. Official Journal L 288/27, 6/11/2007, p 8 .

Gurnell A, Surian N, Zanoni L. 2009. Multi-thread river channels: a perspective on changing European alpine river systems. Aquatic Sci. 71:253-65.

Lenzi M.A., D’Agostino V., Sonda D. 2000. Ricostruzione morfologica e recupero ambientale dei torrenti: Criteri metodologici ed esecutivi. Bios, Cosenza, Italy.

Liébault F., Piégay H. 2001. Assessment of channel changes due to longterm bedload supply decrease, Roubion River, France. Geomorphology 36:167-86.

Loreggian M. 2013. Application of the morphological quality index (IQM) in thirteen reaches of Fiorentina and Cordevole rivers. B.Sc. Thesis, University of Padova, Italy.

Malguzzi P., Grossi G., Buzzi A., Ranzi R., Buizza R. 2006. The 1966 "century" flood in Italy: A meteorological and hydrological revisitation. J. Geophys. Res. D Atmospheres 111:D24106.

Moretto J., Rigon E., Mao L., Picco L., Delai F., Lenzi M.A. 2012. Medium- and short-term channel and island evolution in a disturbed gravel bed river (Brenta River, Italy). J. Agric. Eng. 43:e27.

Palmer M.A., Bernhardt E.S., Allan J.D., Lake P.S., Alexander G., Brooks S., Carr J., Clayton S., Dahm C.N., Shah J.F., Galat D.L., Loss S.G., Goodwin P., Hart D.D., Hassett B., Jenkinson R., Kondolf G.M., Lave R., Meyer J.L., O'Donnell T.K., Pagano L., Sudduth E. 2005. Standard for ecologically successful river restoration. J. Appl. Ecol. 42:208-17.

Picco L., Mao L., Rigon E., Moretto J., Ravazzolo D., Delai F., Lenzi M.A. 2012. An update of the sediment fluxes investigation in the Rio Cordon (Italy) after 25 years of monitoring. J. Agric. Eng. 43:e17. 
Rigon E., Comiti F., Lenzi M.A. 2012a. Large wood storage in streams of the Eastern Italian Alps and the relevance of hillslope processes. Water Resour. Res. 48:W01518.

Rigon E., Moretto J., Mao L., Picco L., Delai F., Ravazzolo D., Lenzi M.A., Kaless G, 2012b. Thirty years of vegetation cover dynamics and planform changes in the Brenta River (Italy): implications for channel recovery. IAHS Publication 356:178-86.

Rinaldi M., Surian N., Comiti F., Bussettini M., 2012. Guidebook for the evaluation of stream morphological conditions by the morphological quality index (MQI). Version 1.1. Istituto Superiore per la Protezione e la Ricerca Ambientale, Roma, Italy.

Rinaldi M., Surian N., Comiti F., Busettini M., 2013. A method for the assessment and analysis of the hydromorphological condition of Italian streams: the morphological quality index (MQI). Geomorphology 180-1:96-108.

Strahler A.N. 1964. Quantitative geomorphology of drainage basins and channel networks. In: T. Chow (ed.) Handbook of applied hydrology, section 4-IIV. McGraw-Hill, New York, USA, pp 39-76.

Surian N., Ziliani L., Comiti F., Lenzi M.A., Mao L. 2009. Channel adjustments and alteration of sediment fluxes in gravel-bed rivers of north-eastern Italy: potentials and limitations for channel recovery. River Res. Applicat. 25:551-67.

Vangelista M. 2011 Application of the morphological quality index (IQM) in two reaches of the Adige River. B.Sc. Thesis, University of Padova, Italy.

Vaughan I.P., Diamond M., Gurnell A.M., Hall K.A., Jenkins A., Milner N.J., Naylor L.A., Sear D.A., Woodward G., Ormerod S.J. 2009. Integrating ecology with hydromorphology: a priority for river science and management. Aquatic Conserv. Marine Freshwater Ecosyst. 19:113-25.

Zorzi A. 2013. Hydromorphological evaluation (IDRAIM) and application of the morphological quality index (IQM) through advanced GIS analysis on the rio Cordevole (BL). B.Sc. Thesis, University of Padova, Italy. 